Ayudya

Sri Amanda
Enda Puspitasari $^{2}$
Ria Novianti $^{3}$

\section{PERBEDAAN SIKAP KEPEMIMPINAN ANAK USIA 5-6 TAHUN BERDASARKAN JENIS KELAMIN}

\begin{abstract}
Abstrak
Berdasarkan hasil observasi peneliti, diketahui bahwa dalam proses pembelajaran terdapat perbedaan sikap kepemimpinan anak yang berjenis kelamin laki-laki dan perempuan. Penetian ini bertujuan untuk mengetahui perbedaan sikap kepemimpinan anak yang berjenis kelamin laki-laki dan anak yang berjenis kelamin perempuan. Penelitian ini dapat dikategorikan sebagai penelitian kausal komparatif yang bersifat expost facto dengan jumlah populasi 102 orang anak dan sampel berjumlah 60 orang anak menggunakan simple random sampling. Teknik pengumpulan data dalam penelitian ini adalah menggunakan lembar observasi dalam bentuk google form. Teknik analis data menggunakan uji t-test dengan menggunakan program spss 23 . Hasil analisis data diperoleh nilai $0,000<0,05$. Dapat disimpulkan bahwa terdapat perbedaan signifikan sikap kepemimpinan anak yang berjenis kelamin laki-laki dan anak yang berjenis kelamin perempuan.
\end{abstract}

Kata Kunci: Sikap Kepemimpinan, Jenis Kelamin.

\begin{abstract}
Based on the results of the researchers' observations, it is known that in the learning process there are differences in the leadership attitudes of boys and girls. This research aims to determine the differences in leadership attitudes of male children and female children. This research can be categorized as a comparative causal study which is ex post facto with a population of 102 children and a sample of 60 children using simple random sampling. The data collection technique in this study is to use an observation sheet in the form of google form. The data analysis technique used the t-test test using the SPSS 23 program. The results of data analysis obtained value of $0.000<0.05$. It can be concluded that there are significant differences in the leadership attitude of boys and girls.
\end{abstract}

Keywords: Leadership Attitude, Gender.

\title{
PENDAHULUAN
}

Pendidikan Anak Usia Dini (PAUD) adalah suatu upaya pembinaan yang ditujukan kepada anak sejak lahir sampai dengan usia enam tahun yang dilakukan melalui pemberian rangsangan pendidikan untuk membantu pertumbuhan dan perkembangan jasmani dan rohani agar anak

\footnotetext{
123 Program Studi Pendidikan Guru Pendidikan Anak Usia Dini, Fakultas Keguruan dan Ilmu Pendidikan, Universitas Riau

${ }^{1}$ Alamat email ayundattt9@gmail.com

2 Alamat email enda.puspitasari@lecturer.unri.ac.id

${ }^{3}$ Alamat email ria.novianti@ lecturer.unri.ac.id
} 
memiliki kesiapan dalam memasuki pendidikan lebih lanjut (Undang-Undang Nomor 20 Tahun 2003). Pendidikan anak usia dini memiliki peranan yang sangat penting untuk mengembangkan kepribadian anak serta mempersiapkan mereka memasuki jenjang pendidikan selanjutnya. Dalam dokumen Kurikulum berbasis Kompetensi (2004) ditegaskan bahwa pendidikan bagi anak usia dini adanya pemberian upaya untuk menstimulasi, membimbing, mengasuh dan pemberian kegiatan pembelajaran yang akan menghasilkan kemampuan dan keterampilan pada anak.

Setiap anak memiliki bakat dan kemampuan yang berbeda-beda, pada masa kanak-kanak awal, anak mulai belajar mengenali dirinya sendiri. Apa potensi dasar yang dimiliki, dengan mengenali diri maka ia mampu mengembangkan potensinya tersebut secara lebih optimal. Salah satunya adalah jiwa kepemimpinan.Pemimpin berasal dari kata dasar 'pimpin' yang dalam kamus besar Bahasa Indonesia bermakna pekerjaan mengepalai, menuntun, memandu agar dapat mengerjakan sendiri. Artinya, 'pemimpin' adalah individu yang melakukan kegiatan pemanduan tersebut atau orang yang mengampu tanggung jawab memandu. Agar mampu menjadi pemimpin yang baik diperlukan serangkaian keterampilan agar dapat memandu orang lain dengan baik dan benar. Menurut Ngalim Purwanto (dalam Masduki, 2016) mendefinisikan kepemimpinan dengan sekumpulan dari serangkaian kemampuan dan sifat-sifat kepribadian, termasuk didalamnya kewibawaan untuk dijadikan sebagai sarana dalam rangka meyakinkan yang dipimpinnya agar meraka mau dan dapat melaksanakan tugas-tugas yang dibebankan kepadanya dengan rela, penuh semangat,ada kegembiraan batin, serta tidak merasa terpaksa.

Sikap kepemimpinan adalah suatu sikap pribadi yang mampu mengembangkan potensi diri, mampu menempatkan diri serta mampu berfikir terbuka dan positif terhadap diri dan lingkungan. Adapun sikap kepemimpinan ini tidak hadir dengan sendirinya melainkan dibangun dan dibentuk oleh pilar-pilar pendidikan yaitu keluarga, sekolah dan masyarakat. Menurut Nawawi (2004) terdapat beberapa indikator terbentuknya sikap kepemimpinan yaitu percaya diri, jujur atau dapat dipercaya, disiplin, tanggung jawab dan kerjasama.

Dalam kamus besar bahasa Indonesia jenis berarti yang mempunyai ciri (sifat, keturunan, dan sebagainya). sedangkan kelamin adalah sifat jasmani atau rohani yang membedakan dua makhluk sebagai betina dan jantan atau wanita dan pria. Sehingga jenis kelamin dapat diartikan ciri atau sifat jasmani atau rohani yang membedakan dua makhluk wanita dan pria. Menurut Siti Mutmainah (2006) jenis kelamin adalah suatu konsep analisis yang digunakan untuk mengidentifikasi perbedaan antara laik-laki dan perempuan dilihat dari sudut non biologis, yaitu aspek sosial, budaya, maupun psikologis. Jadi dapat disimpulkan jenis kelamin adalah ciri atau sifat jasmani atau rohani yang membedakan antara laki-laki dan perempuan dan perbedaan dari segi non biologis.

Berdasarkan observasi yang dilakukan peneliti di TK Negeri Pembina 2 Kota Pekanbaru ditemukan beberapa anak masih (1) kurang mampu bekerja sama hal ini dapat dilihat saat selesai bermain anak tidak mau merapikan kembali mainan secara bersama-sama, (2) beberapa anak memiliki tingkat keepercayaan diri yang rendah, hal ini terlihat ketika anak tersebut ditunjuk oleh gurunya untuk memimpin kegiatan baris-berbaris, anak tersebut menangis dan tidak mau tampil didepan, (3) beberapa anak lainnya memiliki sikap kurang jujur hal ini dapat dilihat ketika anak menangis dan ditanya penyebabnya oleh guru dia berbohong, (4) anak kurang disiplin dan (5) tidak mandiri hal ini dapat dilihat saat anak sering terlambat datang kesekolah, dan saat ditinggal oleh orang tuanya anak menangis, (6) anak memiliki tingkat kepedulian dan tanggung jawab yang rendah hal ini dapat dilihat saat temannya meminta tolong anak tidak mau menolong dan saat anak diberi tugas anak tidak mau mengerjakan tugas dan memilih bermain. Maka dari fenomena yang ada peneliti memfokuskan pada sikap kepemimpinan anak. Tujuan dari penelitian ini adalah untuk mengetahui perbedaan sikap kepemimpinan anak yang berjenis kelamin laki-laki dan anak yang berjenis kelamin perempuan di TK Negeri Pembina Kota Pekanbaru. 


\section{METODE}

Penelitian ini adalah penelitian kuntitatif dengan jenis penelitian komparatif yang bersifat Expost Facto, dilakukan secara online dengan menyebarkan lembar observasi berbentuk google form untuk diisi oleh responden yaitu orang tua/wali murid secara online yang dilaksanakan pada bulan Mei-Juni 2020. Menurut Suharsimi Arikunto (2010) populasi adalah wilayah keseluruhan subjek atau objek penelitian. Jadi populasi dalam penelitian ini adalah anak usia 5-6 tahun di TK Negeri Pembina 2 Kota Pekanbaru yang berjumlah 102 orang anak. Dalam teknik pengambilan sampel ini peneliti menggunakan Random Sampling, maka sampel dalam penelitian ini adalah anak usia 5-6 tahun yang berjumlah 60 orang anak diantaranya 30 orang anak laki-laki dan 30 orang anak perempuan. Teknik pengumpulan data dalam penelitian ini adalah dengan menyebar lembar observasi yang berbentuk google form, teknik analisis data dilakukan dengan uji t.

Variabel - variabel dalam penelitian ini adalah sebagai berikut:

Variabel $\mathrm{X}_{1} \quad$ : Anak laki-laki

Variabel $\mathrm{X}_{2} \quad$ :Anak perempuan

Variabel Y : Sikap Kepemimpinan

Data yang di gunakan dalam penelitian ini merupakan data primer yaitu data yang diperoleh langsung dari responden yang akan diteliti. Intrumen yang digunakan adalah berbentuk observasi terstruktur.

Tabel 2.1 Kisi-Kisi Lembar Observasi Sikap Kepemimpinan Anak Usia 5-6 Tahun

No Indikator

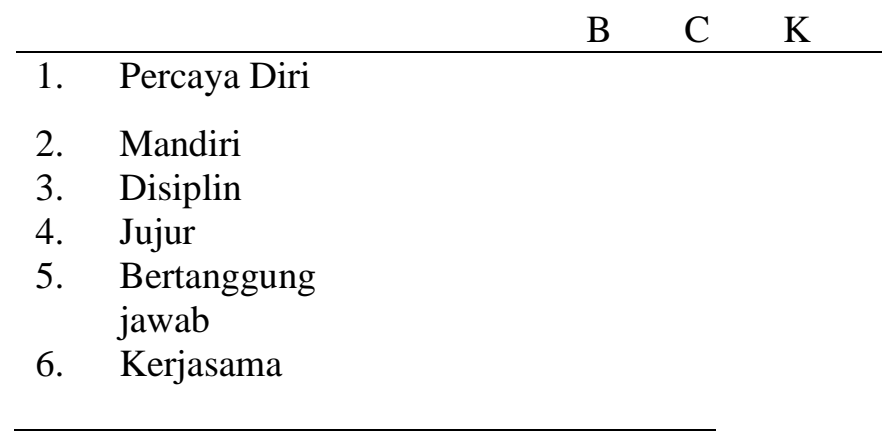

Sumber: Nawawi, 2004

Kriteria Penilaian:

Baik (B) : Diberi skor 3, apabila anak memunculkan perilaku sesuai dengan indikator yangsudah

ada.

Cukup (C) : Diberi skor 2, apabila anak mulai memunculkan perilaku sesuai dengan indikator yang sudah ada.

Kurang (K) : Diberi skor 1, apabila anak belum memuculkan perilaku sesuai dengan indikator yang sudah ada.

\section{HASIL DAN PEMBAHASAN}

Untuk mendapatkan data sikap kepemimpinan anak usia 5-6 tahun di TK Pembina 2 Kota Pekanbaru, maka Pengambilan data dilakukan menggunakan lembar observasi dalam bentuk 
google form yang alternatif jawabannya telah disediakan. Lembar observasi ini sudah disebar sejak tanggal 21 mei-04 juni 2020 melalui grup WhatssApp Orang Tua/Wali murid. Analisis data dilakukan dengan teknik statistic t-tes dengan bantuan SPSS Windows ver.23. teknik statistik $t$-test digunakan untuk membandingkan apakah kedua variabel tersebut sama atau berbeda. Tujuan penelitian ini adalah untuk mengetahui perbedaan sikap kepemimpinan anak usia 5-6 tahun di TK Negeri Pembina 2 Kota Pekanbaru.

Tabel 1 Gambaran Umum Sikap Kememimpinan Anak Usia 5-6 Tahun yang Berjenis Kelamin Laki-Laki di TK Pembina 2 Kota Pekanbaru.

\begin{tabular}{cccccc}
\hline No & Indikator & Skor & Skor & & \\
Ideal & Faktual & $\%$ & Kategori \\
\hline 1 & Percaya Diri & 90 & 72 & $80 \%$ & Baik \\
2 & Mandiri & 90 & 68 & $76 \%$ & Baik \\
3 & Disiplin & 90 & 67 & $74 \%$ & Cukup \\
4 & Jujur & 90 & 74 & $82 \%$ & Baik \\
5 & Bertanggung & & & & \\
5 & Jawab & 90 & 68 & $76 \%$ & Baik \\
6 & Kerja sama & 90 & 70 & $78 \%$ & Baik \\
\hline & Jumlah & 540 & 419 & & \\
& Rata-rata & 90 & 69,83 & $78 \%$ & Baik \\
\hline
\end{tabular}

Berdasarkan tabel diatas dapat diketahui bahwa pada skor akhir tertinggi terdapat pada indikator 4 yaitu jujur dengan skor factual 74 , persentase $82 \%$ yang berada pada kriteria Baik. Skor akhir terendah terdapat pada indikator 3 yaitu disiplin dengan skor factual 67, persentase $74 \%$ yang berada pada kriteria Cukup.

Tabel 2 Sikap Kepemimpinan Anak Usia 5-6 Tahun yang Berjenis Kelamin Lakilaki di TK Pembina 2 Kota Pekanbaru.

\begin{tabular}{ccccc}
\hline No & Kriteria & Rentang Skor & F & $\%$ \\
\hline 1 & Baik & $76 \%-100 \%$ & 16 & $53,33 \%$ \\
2 & Cukup & $56 \%-75 \%$ & 13 & $43,33 \%$ \\
3 & Kurang & $0-55 \%$ & 1 & $3,33 \%$ \\
\hline & Jumlah & & 30 & $100,00 \%$
\end{tabular}

Sumber: Olahan Data Penelitian 2020

Berdasarkan tabel diatas maka dapat diketahui bahwa Sikap Kepemimpinan pada Anak Usia 5-6 tahun yang berjenis kelamin laki-laki di TK Pembina 2 Kota pekanbaru, diperoleh data anak yang berada pada kategori Baik Sebanyak 16 orang anak dengan persentase 53,33\% anak yang berada pada kategori Cukup sebanyak 13 orang anak dengan persentase 43,33\%, dan anak yang berada pada kategori Kurang sebanyak 1 orang anak dengan persentase 3,33\%.

Tabel 3 Gambaran Umum Sikap Kepemimpinan Anak Usia 5-6 Tahun yang yang Berjenis Kelamin Perempuan di TK Pembina 2 Kota Pekanbaru.

\begin{tabular}{clcccc}
\hline No & \multicolumn{1}{c}{ Indikator } & $\begin{array}{c}\text { Skor } \\
\text { Ideal }\end{array}$ & $\begin{array}{c}\text { Skor } \\
\text { Faktual }\end{array}$ & $\%$ & Kategori \\
\hline 1 & Percaya Diri & 90 & 72 & $80 \%$ & Baik \\
2 & Mandiri & 90 & 72 & $80 \%$ & Baik \\
3 & Disiplin & 90 & 71 & $79 \%$ & Baik
\end{tabular}




\begin{tabular}{rlcccc}
4 & Jujur & 90 & 80 & $89 \%$ & Baik \\
5 & Bertanggung Jawab & 90 & 73 & $81 \%$ & Baik \\
6 & Kerja sama & 90 & 73 & $81 \%$ & Baik \\
\hline \multicolumn{2}{c}{ Jumlah } & 540 & 441 & & \\
& Rata-rata & 90 & 73,5 & $82 \%$ & Baik \\
\hline
\end{tabular}

Sumber: Olahan Data Penelitian 2020

Berdasarkan tabel diatas dapat diketahui bahwa pada skor akhir tertinggi terdapat pada indikator 4 yaitu jujur dengan skor factual 80 , persentase $89 \%$ yang berada pada kriteria Baik. Skor akhir terendah terdapat pada indikator 3 yaitu disiplin dengan skor factual 71, persentase $79 \%$ yang berada pada kriteria Baik.

Tabel 4 Sikap Kepemimpinan Anak Usia 5-6 Tahun yang Berjenis Kelamin Perempuan di TK Pembina 2 Kota Pekanbaru.

\begin{tabular}{ccccc}
\hline No & Kriteria & Rentang Skor & F & $\%$ \\
\hline 1 & Baik & $76 \%-100 \%$ & 23 & $77 \%$ \\
2 & Cukup & $56 \%-75 \%$ & 7 & $23 \%$ \\
3 & Kurang & $0-55 \%$ & 0 & $0 \%$ \\
\hline & Jumlah & & 30 & $100 \%$ \\
\hline
\end{tabular}

Berdasarkan tabel diatas maka dapat diketahui bahwa Sikap Kepemimpinan pada Anak Usia 5-6 tahun yang berjenis kelamin perempuan di TK Pembina 2 Kota pekanbaru, diperoleh data anak yang berada pada kategori Baik Sebanyak 23 orang anak dengan persentase $77 \%$ anak yang berada pada kategori Cukup sebanyak 7 orang anak dengan persentase $23 \%$, dan anak yang berada pada kategori Kurang sebanyak 0 orang anak dengan persentase $0 \%$

\section{Uji Prasyarat dan Analisis \\ a. Uji Linearitas}

Uji linearitas bertujuan untuk mengetahui apakah data yang dimiliki sesuai dengan garis linear atau tidak (apakah ada hubungan antara variabel hendak dianalisis mengikuti garis lurus atau tidak).

\section{Tabel 5 Uji Linearitas}

\begin{tabular}{|c|c|c|c|c|c|c|c|}
\hline \multicolumn{8}{|c|}{ ANOVA Table } \\
\hline & & & $\begin{array}{l}\text { Sum of } \\
\text { Squares }\end{array}$ & Df & $\begin{array}{l}\text { Mean } \\
\text { Square }\end{array}$ & $\mathrm{F}$ & Sig. \\
\hline Jenis & Between & (Combined) & 58.376 & 7 & 8.339 & 2.666 & .037 \\
\hline Kelamin & Groups & Linearity & 27.034 & 1 & 27.034 & 8.641 & .008 \\
\hline $\begin{array}{l}\text { Perempuan * } \\
\text { Jenis }\end{array}$ & & $\begin{array}{l}\text { Deviation } \\
\text { from Linearity }\end{array}$ & 31.343 & 6 & 5.224 & 1.670 & 176 \\
\hline Kelamin & Within Groups & & 68.824 & 22 & 3.128 & & \\
\hline Laki Laki & Total & & 127.200 & 29 & & & \\
\hline
\end{tabular}

Sumber: Olahan Data Penelitian 2020

Berdasarkan tabel di atas menunjukkan hasil pengujian linearitas data sikap kepemimpinan anak yang berjenis kelamin laki-laki dan yang berjenis kelamin perempuan sebesar 0,037. 
Artinya adalah nilai sig combined lebih kecil dari $0,05 \quad(0,037<0,05)$. Sehingga dapat disimpulkan bahwa hubungan antara sikap kepemimpinan anak yang berjenis kelamin laki-laki dan yang berjenis kelamin perempuan adalah linear.

\section{b. Uji Homogenitas}

Pengujian homogenitas dimaksudkan untuk memberikan keyakinan bahwa sekumpulan data yang dimanipulasi dalam serangkaian analisis memang berasal dari populasi yang tidak jauh berbeda keragamannya. Analisis homogenitas dalam pengujian ini menggunakan uji chisquare test dengan bantuan program SPSS versi 23 . Kolom yang dilihat pada print out ialah kolom Sig. Jika nilai pada kolom Sig.>0,05 maka Ho diterima.

Tabel 6 Uji Homogenitas

Test of Homogeneity of Variances

\begin{tabular}{cccc}
\hline Levene Statistic & df1 & df2 & Sig. \\
\hline 1.053 & 6 & 22 & .419
\end{tabular}

Sumber: Olahan Data Penelitian 2020

Berdasarkan dari tabel diatas diperoleh nilai Asymp Sig 0,419 yang berarti lebih besar dari 0,05 maka Ho diterima. Sehingga dapat disimpulkan bahwa kedua kelompok homogen atau mempunyai varians yang sama.

\section{c. Uji Normalitas}

Uji normalitas dilakukan untuk menentukan apakah sebaran data berdistribusi normal atau tidak. Penelitian menggunakan uji normalitas dengan cara Kolmogrof (uji K-S sample) pada SPSS 23. Hasil dari uji normalitas dapat dilihat dari tabel berikut:

Tabel 7 Uji Normalitas

\begin{tabular}{llrr}
\multicolumn{4}{c}{ One-Sample Kolmogorov-Smirnov Test } \\
\hline & & $\begin{array}{c}\text { Jenis Kelamin } \\
\text { Laki Laki }\end{array}$ & $\begin{array}{c}\text { Jenis Kelamin } \\
\text { Perempuan }\end{array}$ \\
\hline $\mathrm{N}$ & & 30 & 30 \\
Normal Parameters & Mean & 13.3000 & 11.4000 \\
& Std. Deviation & 2.69290 & 2.09433 \\
Most Extreme Differences & Absolute & .156 & .146 \\
& Positive & .125 & .121 \\
& Negative & -.156 & -.146 \\
Test Statistic & & .156 & .146 \\
Asymp. Sig. (2-tailed) & & $.062^{\mathrm{c}}$ & $.102^{\mathrm{c}}$ \\
\hline
\end{tabular}
a. Test distribution is Normal.
b. Calculated from data.
c. Lilliefors Significance Correction.

Data dikatakan normal jika tingkat Sig. Pada Kolmogrov-Smirnov lebih besar dari 0,05 maka data didistribusikan normal, jika kurang dari 0,05 maka data didistribusikan tidak normal. Nilai Sig. Anak berjenis kelamin laki-laki 0,062 dan nilai Sig. Anak berjenis kelamin perempuan sebesar 0,102. Nilai tersebut menunjukkan bahwa Sig.>0,05 maka Ho diterima, data tersebut berdistribusi normal. 


\section{d. Uji Hipotesis}

Uji hipotesis dalam penelitian ini menggunakan metode $t$-tes untuk melihat sikap kepemimpinan anak usia 5-6 tahun yang berjenis kelamin laki-laki dan yang berjenis kelamin perempuan. Sikap kepemimpinan anak yangberjenis kelamin laki-laki dan perempuan dikatakan berbeda secara signifikan jika Sig. $<0,05$. Jika Sig. $<0,05$ maka Ho ditolak, Ha diterima

Tabel 3.8 Uji Hipotesis

Paired Samples Test

Paired Differences

\begin{tabular}{|c|c|c|c|c|c|c|c|c|c|}
\hline \multirow{3}{*}{$\begin{array}{l}\text { Pair } \\
1\end{array}$} & \multirow{2}{*}{ Jenis Kelamin } & \multirow[b]{2}{*}{ Mean } & \multicolumn{6}{|c|}{$\begin{array}{l}\text { 95\% Confidence } \\
\text { Interval of the }\end{array}$} & \multirow{2}{*}{$\begin{array}{l}\text { Sig. (2- } \\
\text { tailed) }\end{array}$} \\
\hline & & & Deviation & Mean & Lower & Upper & $\mathrm{t}$ & $\mathrm{df}$ & \\
\hline & $\begin{array}{l}\text { Laki Laki - } \\
\text { Jenis Kelamin } \\
\text { Perempuan }\end{array}$ & 1.90000 & 2.53731 & .46325 & .95255 & 2.84745 & 4.101 & 29 & .000 \\
\hline
\end{tabular}

Sumber: Olahan Data Penelitian 2020

Berdasarkan hasil uji menggunakan Paired sample t-test, diperoleh nilai 0,000 $<0,05$. Maka dapat disimpulkan bahwa terdapat perbedaan signifikan sikap kepemimpinan anak yang berjenis kelamin laki-laki dan perempuan.

\section{PEMBAHASAN}

Sikap Kepemimpinan merupakan salah satu sikap yang mampu mengembangkan potensi diri. Sikap Kepemimpinan mampu membuat anak dapat menempatkan diri serta mampu berfikir terbuka dan positif terhadap diri dan lingkungan. Adapun sikap kepemimpinan ini tiak hadir dengan sendirinya melainkan dibangun dan dibentuk oleh pilar-pilar pendidikan yaitu keluarga, sekolah, dan masyarakat. Menurut Veithzal Rivai (2004:3) kepemimpinan merupakan seni mempengaruhi dan mengarahkan orang dengan cara kepatuhan, kepercayaan, kehormatan, san kerjasama yang bersemangat dalam mencapai tujuan bersama. Seorang pemimpin memiliki sikap bertanggung jawab, berani menyampaikan ide, menginisiasi ide, percaya diri, dan mengambil keputusan secara mandiri. Ria (2018) menyatakan bahwa pada anak perlu dikembangkan resiliensi yakni ketahanan ketika menghadapi permasalahan. Hal ini tentunya juga akan mempengaruhi sikap kepemimpinan pada anak. Selanjutnya Ria dan Meyke (2020) menyatakan bahwa pada saat sekarang di mana gadget menjadi bagian dari kehidupan, anak perlu memiliki kemampuan untuk memilih dan bersikap sehingga dapat mengendali diri saat menggunakan gadget. Hal ini juga adalah bagian dari sikap kepemimpinan yang perlu dikembangkan pada anak.

Pengambilan data yang dilakukan peneliti yaitu menggunakan lembar observasi yang berbentuk google form. Menurut Piyoto Budi Santoso(2019) Google Form sebagai media penilaian memiliki beberapa kelebihan yaitu, sangat mudah digunakan, dapat dinikmati secara gratis, programnya cukup ringan, bisa dibagikan ke beberapa platform sehingga semua orang bisa mengisi kuesioner, memiliki fitur SpreadsSheets sehingga dapat melihat tanggapan survei secara otomatis. Adapun pelaksanaan penelitian menggunakan google form ini memberi berbagai manfaat bagi orang tua/wali murid yang berkaitan dengan kemampuan orang tua/wali memahami anak, peningkatan pembelajaran dan pelayanan pendidikan sesuai dengan kebutuhan masing-masing anak. Dalam hal ini, google form digunakan peneliti untuk menilai sikap kepemimpinan anak yang berjenis kelamin laki-laki dan yang berjenis kelamin perempuan. 
Berdasarkan analisis pengololaan data dan hasil persentase di atas dapat dilihat hasil sikap kepemimpinan anak usia 5-6 Tahun yang berjenis kelamin laki-laki di TK Pembina 2 Kota Pekanbaru diperoleh jumlah nilai 419 dengan rata-rata persentase $78 \%$. Skor akhir tertinggi terdapat pada indikator yaitu "jujur" dengan skor 74 dengan persentase $82 \%$. Kemudian skor terendah terdapat pada indikator yaitu "Disiplin" dengan jumlah skor 67 dengan persentase $74 \%$.

Berdasarkan google form anak yang berjenis kelamin laki-laki, pada indikator "Percaya diri" diperoleh skor 72 atau $80 \%$ dari yang diharapkan. Artinya, pada indikator pertama pencapainnya sudah baik. Lauster (1978) rasa percaya diri bukan merupakan sifat yang diturunkan (bawaan) melainkan diperoleh dari pengalaman hidup, serta dapat diajarkan dan ditanamkan melalui pendidikan, sehingga upaya-upaya tertentu dapat dilakukan guna membentuk dan meningkatkan rasa percaya diri. Pada indikator "Mandiri" diperoleh skor 68 atau $76 \%$ dari yang diharapkan. Artinya, pada indikator kedua pencapainnya sudah baik. Menurut Montessori (dalam Damayanti, 2020) orang dewasa berperan dalam membantu anak untuk meniti jalan menuju kemandirian. Artinya, oran tua memberi kesempatan untuk anak agar dapat melekukannya sendiri, hal ini dapat memberikan rasa puas pada anak ketika dia berhasil mencapai tujuannya. Selanjutnya, pada indikator "Disiplin" diperoleh skor 67 atau $74 \%$ dari yang diharapkan. Artinya, indikator ketiga pencapainnya cukup baik. Pendley (2008) mengemukakan bahwa disiplin merupakan bagian dari proses penerapan self-responsibility pada anak. Ketika anak bisa mengembangkan rasa tanggung jawab kepada dirinya untuk mengembangkan potensi dan karakter serta mempuat pilihan yang tepat, hal inilah yang disebut disiplin.

Pada indikator "Jujur" diperoleh skor 74 atau $82 \%$ dari yang diharapkan. Artinya, indikator keempat pencapainnya sudah baik. Kesuma, dkk (2012:6) mengungkapkan lebih lanjut bahwa kejujuran sangat penting diterapkan disekolah sebagai karakter anak-anak Indonesia saat ini. Pada indikator "Bertanggung jawab" diperoleh skor 68 atau 76\% dari yang diharapkan. Artinya, indikator kelima pencapainnya sudah baik. Seperti yang diungkapkan Rohayati (2015:2) cara bertanggung jawab yang dilakukan oleh peserta didik mengerjakan tugas hingga selesai, dan dapat menghargai waktu. Pada indikator "Kerjasama" diperoleh skor 70 atau 78\% dari yang diharapkan. Artinya, indikator terakhir pencapainnya sudah baik. Ria dan Ilga (2020) berpendapat bahwa Kerjasama ditumbuhkan dari keluarga. Pembagian tugas sehari-hari di rumah dan bagaimana orang tua dan anak, juga anak dengan saudaranya menyelesaikan tugas tersebut secara Bersama akan menumbuhkan kemampuan bekerja sama sejak dini.

Untuk melihat kondisi subjek secara keseluruhan, peneliti mengelompokkan subjek ke dalam tiga kategori yaitu baik, cukup, kurang. Pada kategori baik terdapat 16 orang anak dengan presentase 53,33\% pada kategori cukup terdapat 13 orang anak dengan presentase 43,33\%, dan pada kategori kurang terdapat 1 orang anak dengan persentase 3,33\%. Berdasarkan presentase yang diperoleh subjek secara keseluruhan pada anak yang berjenis kelamin laki-laki $78 \%$ yang berarti sikap kepemimpinan anak berada pada kategori baik.

Selanjutnya analisis pengolahan data anak yang berjenis kelamin perempuan di TK Pembina 2 Kota Pekabaru diperoleh jumlah nilai 441 dengan rata-rata persentase 82\%. Skor akhir tertinggi terdapat pada indikator yaitu "jujur" dengan skor 80 dengan persentase $89 \%$. Kemudian skor terendah terdapat pada indikator yaitu "Disiplin" dengan jumlah skor 71 dengan persentase $79 \%$. Berdasarkan hasil penelitian anak yang berjenis kelamin perempuan, pada indikator "Percaya diri" diperoleh skor 72 atau $80 \%$ dari yang diharapkan. Artinya, pada indikator pertama pencapainnya sudah baik. Pada indikator "Mandiri" diperoleh skor 72 atau 
80\% dari yang diharapkan. Artinya, pada indikator kedua pencapainnya sudah baik. Selanjutnya, pada indikator "Disiplin" diperoleh skor 71 atau $79 \%$ dari yang diharapkan. Artinya, indikator ketiga pencapainnya sudah baik.

Pada indikator "Jujur" diperoleh skor 80 atau $89 \%$ dari yang diharapkan. Artinya, indikator keempat pencapainnya sudah baik. Pada indicator"Bertanggung jawab" diperoleh skor 73 atau $81 \%$ dari yang diharapkan. Artinya, indikator kelima pencapainnya sudah baik. Pada indikator "Kerjasama" diperoleh skor 73 atau $81 \%$ dari yang diharapkan. Artinya, indikator terakhir pencapainnya sudah baik.

Dari kondisi subjek secara keseluruhan, peneliti mengelompokkan subjek ke dalam tiga kategori yaitu baik, cukup, kurang. Pada kategori baik terdapat 23 orang anak dengan presentase $77 \%$ pada kategori cukup terdapat 7 orang anak dengan presentase $23 \%$, dan pada kategori kurang terdapat 0 orang anak dengan persentase $0 \%$. Berdasarkan presentase yang diperoleh subjek secara keseluruhan pada anak yang berjenis kelamin perempuan $82 \%$ yang berarti sikap kepemimpinan anak berada pada kategori baik.

Hasil pengujian linearitas data sikap kepemimpinan anak yang berjenis kelamin laki-laki dan yang berjenis kelamin perempuan sebesar 0,037. Artinya adalah nilai sig combined lebih kecil dari $0,05(0,037<0,05)$. Sehingga dapat disimpulkan bahwa hubungan antara sikap kepemimpinan anak yang berjenis kelamin laki-laki dan yang berjenis kelamin perempuan adalah linear. Hasil diperoleh nilai Asymp Sig 0,419 yang berarti lebih besar dari 0,05 maka Ho diterima. Sehingga dapat disimpulkan bahwa kedua kelompok homogen atau mempunyai varians yang sama. Kemudian data dikatakan normal jika jika tingkat Sig. Pada KolmogrovSmirnov lebih besar dari 0,05 maka data didistribusikan normal, jika kurang dari 0,05 maka data didistribusikan tidak normal. Nilai Sig. Anak berjenis kelamin laki-laki 0,062 dan nilai Sig. Anak berjenis kelamin perempuan sebesar 0,102. Nilai tersebut menunjukkan bahwa Sig.>0,05 maka Ho diterima, data tersebut berdistribusi normal.

Penelitian komparatif ini dilakukan untuk mengetahui adanya perbedaan signifikan sikap kepemimpinan anak usia 5-6 tahun yang berjenis kelamin laki-laki dan anak yang berjenis kelamin perempuan. Berdasarkan hasil uji menggunakan paired sample t-test, diperoleh nilai $0,000<0,05$. Maka dapat disimpulkan bahwa terdapat perbedaan signifikan sikap kepemimpinan anak yang berjenis kelamin laki-laki dan perempuan.

Gender merupakan perbedaan antara laki-laki dan perempuan. Dari perbedaan ini, munculan karakteristik seorang pemimpin yang dipengaruhi oleh gender, misalnya pemimpin laki-laki dan perempuan memiliki sifat kepemimpinan yang berbeda. Menurut Egly dan Jonhson gender sorang pemimpin dibedakan dari pemimpin itu sendiri. Dilihat dari sudut pandang, pemimpin laki-laki menggambarkan sosok individu yang kuat, tegas dan berani, sedangkan perempuan menggambarkan sosok yang memperhatikan sifat yang hangat dalam hubungan personal, lebih suka bersosialisasi dengan orang lain (Herachwati,2012).

Berdasarkan penelitian Afrihayana (2009) kepemimpinan perempuan merupakan kemampuan seorang perempuan dalam memimpin, membimbing, mempengaruhi atau mengontrol pikiran, perasaan atau tingkah laku orang lain sehingga orang lain tersebut bertingkah laku sebagaimana dikehendaknya untuk mencapai tujuan bersama.. Antara laki-laki dan perempuan mempunyai hak yang sama untuk emnjadi seorang pemimpin. Asalkan seorang pemimpin itu dapat menjadi contoh, panutan dan menjalankan tugasnya dengan baik. Menurut Dean dan Popp seorang pemimpin harus memiliki jiwa untuk mempengaruhi, yang merupakan hasil diperoleh dari adanya quality communications dan jiwa motivator yang memerlukan 
kemampuan memahami perilaku individu dan kompeten pembentukannya seperti presepsi, sikap, dan kepribadian (Nurrohim,2009).

Hasil penelitian Endarwati (2017) dapat disimpulkan bahwa karakter yang menunjukan sikap sebagai pemimpin perempuan adalah: (a) tidak ambisius, (b) jujur, (c) sabar, (d) teladan yang ditunjukan dengan perilaku disiplin, sederhana dan mandiri, (e) berperilaku tegas. Menurut Yeney (2012) berdasarkan teori agensi perbedaan jenis kelamin pada pemimpin akan mempengaruhi gaya kepemimpinannya. Seorang peimpin perempuan memiliki cara penyampaian yang unik dimana mereka selalu menyediakan dan menyalurkan informasi penting, sedangkan pemimpin laki-laki penyampaian pesannya lebih kepada fakta dan langsung ke inti informasinya.

Sehubung dengan penelitian diatas, kepemimpinan laki-laki dan perempuan memiliki perbedaan. Seorang pemimpin laki-laki cendrung percaya diri, dan tegas, sedangkan pemimpin perempuan memiliki sifat lembut dan bersahabat. Jadi dapat disimpulkan terdapat perbedaan sikap kepemimpinan anak yang berjenis kelamin laki-laki dan anak yang berjenis kelamin perempuan. Dan dapat diketahui sikap kepemimpinan anak usia 5-6 tahun yang berjenis kelamin perempuan lebih tinggi daripada anak yang berjenis kelamin laki-laki di TK Negeri Pembina 2 Kota Pekanbaru.

\section{SIMPULAN}

Berdasarkan analisis data dan pembahasan dalam penelitian ini, maka dapat ditarik kesimpulan sebagai berikut: Sikap kepemimpinan anak usia 5-6 tahun di TK Pembina 2 Kota Pekanbaru yang berjenis kelamin laki-laki tergolong kriteria baik (B) dengan hasil persentase $78 \%$ artinya sikap kepemimpinan anak yang berjenis kelamin laki-laki sudah mencapai sikap kepemimpinan dari yang diharapkan, tetapi pada idikator disiplin anak yang berjenis kelamin laki-laki termasuk kedalam kriteria cukup, artinya masih ada sebagian anak yang masih kurang tingkat kedisipilinannya. Sikap kepemimpinan anak usia 5-6 tahun di TK Pembina 2 Kota Pekanbaru yang berjenis kelamin perempuan tergolong kriteria baik (B) dengan hasil persentase $82 \%$ artinya anak yang berjenis kelamin perempuan sudah mencapai sikap kepemimpinan dari yang diharapkan, artinya pada setiap indikator sikap kepemimpinan sudah tergolong kriteria

baik. Terdapat perbedaan yang signifikan sikap kepemimpinan anak usia 5-6 tahun antara anak yang berjenis kelamin laki-laki dan anak yang berjenis kelamin perempuan di TK Negeri Pembina 2 Kota Pekanbaru. Seorang pemimpin laki-laki cendrung percaya diri, dan tegas, sedangkan pemimpin perempuan memiliki sifat lembut dan bersahabat dan sehubung dengan hasil penelitian ini sikap kepemimpinan anak yg berjenis kelamin perempuan cendrung lebih baik daripada anak yang berjenis kelamin laki laki.

\section{DAFTAR PUSTAKA}

Afifah. Y Jubaedah. M P Ningsih. 2016. Peran Orangtua dalam Penanaman Disiplin Pada Anak Usia Prasekolah Melalui Pembiasaan Di Kelurahan Cihaurgeulis Bandung. Jurnal FamilyEdu. II(2).

Bratama, Pengertian-pengertian Dasar dalam pendidikan Luar biasa, (Jakarta:Depdikbud, 1987), hlm.76

Departemen Pendidikan dan Kebudayaan, 1990, Kamus Besar Bahasa Indonesia, (Jakarta: PN Balai Pustaka), h. 684

Masduki. 2016. Kepemimpinan Pendidikan (meneguhkan Legitimasi dalam Berkomunikasi di Bidang Pendidikan). Bandung: Alfabeta 
Kartini Kartono, "Psikologi Wanita (jilid 1); Mengenal Gadis remaja dan wanita dewasa", (Bandung: CV Mandar Maju, 1989), hlm.193-196

Moh. Khuza'i, Problem Definisi Gender:Kajian atas KonsepNature dan Nurture, dalam (Kalimah : Jurnal Studi Agama dan Pemikiran islam)

Potur, Ayla Ayyildiz dan Omur Barkul, 2009, Gender and Creative Thinking in Education: A Theoretical and Experimental Overview" Jurnal International

Pusat Bahasa Kemendiknas, Kamus Besar Bahasa Indonesia ,hlm.626

P Budi Santoso. 2019. Efektifitas Penggunaan Media Penilaian Google Form Terhadap Hasil

Belajar Pelajaran TIK. Prosiding Seminar Nasional.

Ria Novianti. 2018. Orang Tua Sebagai Pemeran Utama Dalam Menumbuhkan Resiliensi Anak. Jurnal Educhild. 7(1):26-33

Rivai, 2003, Kepemimpinan Pendidikan, (Jakarta: Cahaya Ilmu), h. 3

R Novianti, M Gazia. 2020. Penggunaan Gadget pada Anak; Tantangan Baru Orang Tua

Milenial. Jurnal Obsesi: Jurnal Pendidikan Anak Usia Dini.

R Novianti. I Maria. 2020. Pendidikan Keorangtuan. Yogyakarta: Ellunar Publisher.

R Juwita. A Munajat. Elnawati. 2019. Mengembangkan Sikap Tanggung jawab Melaksanakan

Tugas Sekolah Melalui Metode Bercerita Pada Anak Usia 5-6 Tahun Di TK Aisyiyah Bustanul Athfal 2 Kota Sukabumi. Jurnal Utile. 5(2).

Siagian, Sondang P, 2010. Teori dan Praktek Kepemimpinan. Jakarta: PT. Rineka Cipta Sugioyono. 2010. Metode Penelitian Pendidikan Pendekatan Kuantitatif, Kualitatif, dan P\&D. Alfabeta. Bandung

Suharsimi Arikunto. 2010. Prosedur Penelitian (Suatu Pendekatan Praktek). Rineka Cipta. Jakarta.

Sukardi. 2012. Metodologi Penelitian Pendidikan. Jakarta: Bumi Aksara

Suyadi, Maulidya Ulfah. 2013. Konsep Dasar Paud. Bandung: PT Remaja Rosdakarya

Tim Elmore.2010. Bagaimana Mengasah dan Mengkuhkan Jiwa Kepemimpinan dalam Diri Anak-anak Anda. Jogjakarta: Garailmu

Veithzal Rivai, dkk. 2013. Pemimpin Dan Kepemimpinan Dalam Organisasi. Jakarta: Rajawali Pers,Wirawan, 2013. Kepemimpinan: Teori, Psikologi, perilaku Organisasi, Aplikasi dan Penelitian. Jakarta: Rajawali Pers,

Yudiaatmaja, Fridayana. 2013. Kepemimpinan: Konsep, Teori, dan Karakternya. Jurnal Media Komunikasi(Daring) 